\title{
KARIŪNŲ RANKŲ PSICHOMOTORINIŲ SAVYBIŲ TYRIMAS NAUDOJANT DPA-1 ANALIZATORIŲ
}

\author{
Ilona Judita Zuozienè ${ }^{1}$, Albertas Skurvydas ${ }^{1}$, Dalia Mickevičiené $\dot{1}^{1}$ Rytis Vasiliauskas ${ }^{2}$, \\ Arūnas Krasauskas ${ }^{2}$, Jūratė Kudirkaitė ${ }^{1}$ \\ Lietuvos kūno kultūros akademija ${ }^{I}$, Kaunas, \\ Generolo Jono Žemaičio Lietuvos karo akademija², Vilnius, Lietuva
}

\begin{abstract}
Ilona Judita Zuozienė. Docentẻ socialinių mokslų daktarè. Lietuvos kūno kultūros akademijos Vandens sporto šakų katedros docentė. Mokslinių tyrimų kryptis - sportuojančiujų fizinio parengtumo kontrolès ir treniruotės valdymas.
\end{abstract}

\section{SANTRAUKA}

Tyrimo tikslas — nustatyti reakcijos laiko ir judesiu greičio ypatumus atliekant judesius dešine ir kaire ranka bei kaip jie priklauso nuo judesio sudètingumo. Tyrimo metu siekta atsakyti z šiuos klausimus: 1) ar skiriasi reakcijos laikas bei judesiu greitis atliekant judesi dešine ir kaire ranka; 2) ar priklauso reakcijos laikas ir judesio greitis nиo judesio sudètingumo; 3) kokie tiriamu parametru variacijos rodikliai atliekant judesius dešine ir kaire ranka; 4) ar užduoties sudètingumas turi ìtakos tiriamu parametru rezultatu sklaidai? Tyrimai buvo atlikti LKKA Žmogaus motorikos laboratorijoje naudojant LKKA mokslininku ir UAB „Katra“ specialistu sukurta nauja originalu prietaisq - žmogaus ranku bei koju judesiu dinaminiu parametru analizatoriu DPA-1. Buvo tiriama 50 sveiku

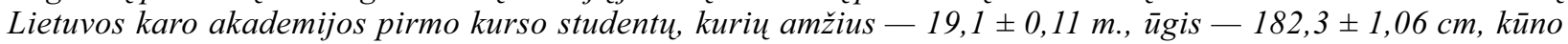
mase $-76,9 \pm 1,13 \mathrm{~kg}$. Tyrimo rezultatai parodè, kad atliekant judesius dešine ir kaire ranka reakcijos laiko rodikliai nesiskyrè $(p<0,05)$, taip pat šio rodiklio nepaveike ir užduoties sudètingumas. Analizuojant judesiu greičio rodikliu priklausomybe nuо užduoties sudètingumo aptikta, kad greita ir tikslu judesí tiriamieji atliko léčiau nei paprasta greita. Reakcijos laiko rodikliu sklaida buvo mažesnè $\left(V_{A \%}\right.$ svyravo nuo 4,0 iki $\left.12,8 \%\right)$ nei judesiu greičio $\left(V_{A \%}\right.$ - nuo 12,3 iki 46,6\%). Užduoties sudetingumas labiau paveiké judesiu greičio nei reakcijos laiko rezultatu sklaida.

Raktažodžiai: reakcijos laikas, judesiu greitis, užduoties sudètingumas.

\section{IVADAS}

$\checkmark$ mogaus motorinè veikla i̇vairiapusiškai ir plačiai tyrinejjama. Tai tarpdisciplininè problema, kurios ivvairius aspektus analizuoja biomedikai, psichofiziologai, pedagogai, sporto mokslininkai (Georgopoulos et al., 1993; Latash, 1998; Kelso, 1999; Enoka, 2002; Wolpert et al., 2003; Stergiou, 2004). Valingi judesiai tyrinèjami analizuojant psichomotorikos, judesių bei judèjimo igūdžių ypatumus. Mokslininkus pastaraisiais metais ypač domina individualūs tipiniai motorikos ypatumai, motorinès elgsenos dèsningumai, judesių lavinimo ir mokymo valdymo modeliai (Rose,
1996; Schmidt, Lee, 1999; Hodges, Franks, 2002), kuriuos lemia žmogaus nervų sistemos veikla. Sporto moksle nuolat ieškoma naujų ir objektyvių motorikos bei nervu sistemos funkcijos tyrimo metodu, norint gauti kuo išsamesnès informacijos apie sportuojančiujų būklę. Lietuvoje tyrimai šioje srityje dažniausiai apsiriboja matuojant paprastą bei sudetingą reakciją ir judesių dažni (Skernevičius ir kt., 2004). Pastaruoju metu yra atlikta darbų, analizuojančiu psichomotorinius reakcijos komponentus bei atliekamo judesio kinematines ir dinamines charakteristikas pagal 
sumodeliuotą žaidimo situaciją (Muckus ir kt., 1999, 2000; Muckus, 2003), tačiau vis dar trūksta originalesnių tyrimų, leidžiančių suvokti žmogaus nervų sistemos veiklos principus valdant judesius (Skurvydas ir kt., 1996; Skurvydas, 1998). LKKA mokslininku ir UAB „Katra“ specialistu buvo sukurtas naujas originalus prietaisas žmogaus rankų ir kojų judesių dinaminių parametrų analizatorius DPA-1 - leidžia tirti reakcijos laiką, kokybiškai išmatuoti vienos rankos ar kojos tikslinius judesius, abiejų ranku ir kojų koordinuotų ar nepriklausomu judesiu dinaminius bei kinematinius parametrus, kai yra pasipriešinimo jèga ir taikinys su labai įvairia programuojama geometrinių, spalviniu bei laikiniu užduodamų parametrų îvairove. DPA-1 gali būti naudojamas ivvairios kvalifikacijos sportininkų ir nesportuojančių, sveikų ir turinčiu sveikatos sutrikimų žmonių judesių psichomotoriniams parametrams testuoti, ivertinti, parengtumui optimizuoti, taip pat sportininkų atrankos metu.

Tyrimo tikslas - nustatyti reakcijos laiko ir judesiu greičio ypatumus atliekant judesius dešine ir kaire ranka bei kaip jie priklauso nuo judesio sudètingumo.

Siekdami užsibrèžto tikslo, stengèmès atsakyti i šiuos klausimus: 1) ar skiriasi reakcijos laikas bei judesiu greitis atliekant judesi dešine ir kaire ranka; 2) ar priklauso reakcijos laikas ir judesio greitis nuo judesio sudetingumo; 3) kokie tiriamu parametru variacijos rodikliai atliekant judesius dešine ir kaire ranka; 4) ar užduoties sudettingumas turi itakos tiriamu parametrų rezultatų sklaidai?

\section{TYRIMO METODIKA}

Tiriamieji - 50 sveiku Lietuvos karo akademijos pirmo kurso studentu. Tiriamuju amžiaus - 19,1 $\pm 0,11 \mathrm{~m}$., ūgis $-182,3 \pm 1,06 \mathrm{~cm}$, kūno masè $-76,9 \pm 1,13 \mathrm{~kg}$. Tiriamieji buvo supažindinti su tyrimo eiga. Tyrimo protokolas aptartas ir patvirtintas Kauno medicinos universiteto biomedicininių tyrimų etikos komitete.

Tyrimai atlikti LKKA Žmogaus motorikos laboratorijoje naudojant žmogaus rankų ir koju judesių dinaminiu parametrų analizatorių DPA-1 (1 pav.).

DPA-1 sudaro du matavimo irenginiai, sujungti su stacionariu standartiniu kompiuteriu su Windows (ar suderinama su ja) operacine aplinka, i kuria iterpta matavimo korta su darbo programa, ir $17^{\prime}$ isstrižainès ekranas. Matavimo įrengini sudaro:

- rankenos judesio transformavimo į šešis kartus sumažintą matavimo zoną mechanizmas;

- rankenos judesio koordinačių matavimo mechanizmas;

- jègos, veikiančios į rankena, modulio horizontalios dedamosios nustatymo mechanizmas su jègos matavimo elementu;

- programuojamo pasipriešinimo jègos formavimo elektromagnetinis mechanizmas;

- jègos matavimo mazgas;

- programuojamo pasipriešinimo jègos valdymo mazgas;

- maitinimo šaltinis.

Matavimo įrenginiai tvirtinami prie atraminès plokštès, kurios paviršiumi slankioja rankenų mazgai. Matavimo įrenginių priekinejje dalyje imontuoti maitinimo jungikliai su maitinimo itampos indikatoriais, užpakalineje - jungtys maitinimo kabeliui ir nuotoliniam starto mygtukui.

DPA-1 prietaisas leidžia tirti reakcijos laiką, judesių dinamines ir kinematines charakteristikas.

Reakcijos laiko ir judesio greičio tyrimas. Tiriamieji sodinami i specialią kèdę prie stalo, ant kurio pritvirtintas analizatorius DPA-1. Nugara tiesi ir atremta į kèdès atlošą, abi rankos sulenktos per alkūnès sąnarị $90^{\circ}$ kampu taip, kad žastai būtų priglausti prie šonu, dilbiai - remtųsi i żrenginio atraminę plokštę. Kojos sulenktos $90^{\circ}$ kampu per kelius ir pedomis remiasi i grindis. Viena ranka paimama prietaiso rankena. Irenginio kèdès padètis yra reguliuojama taip, kad tiriamasis atsisèstu patogiai užimdamas standartizuotą padètį.

Pagal iš anksto sudarytų testų užduotis, ekrane nustatytu laiko momentu pasirodo taikinys žalias apskritimas. Kiekvieno testo metu tiriamasis pastato rankenos simboli kompiuterio ekrane i starto zoną ir, pasiruošęs testui, paspaudžia starto mygtuką. Programa po nustatyto laiko generuoja tam tikroje vietoje ir pasirinktos formos taikini, $\mathfrak{i}$ kurį tiriamasis turi sureaguoti stumdamas rankena. Matavimo ciklas baigiamas atlikus judesi arba pataikius ị taikini (priklausomai nuo užduoties). Informacija apie judesi kaupiama kompiuterio atmintyje. Vèliau, analizuojant judesio laiko ir kinematinių rodiklių kreives, išmatuojamas reakcijos laikas nuo taikinio pasirodymo iki to momento, kai jẻga ỉ rankeną pasiekia slenkstinę reikšmę $(0,1 \mathrm{~kg})$, bei kiti judesio dinaminiai 


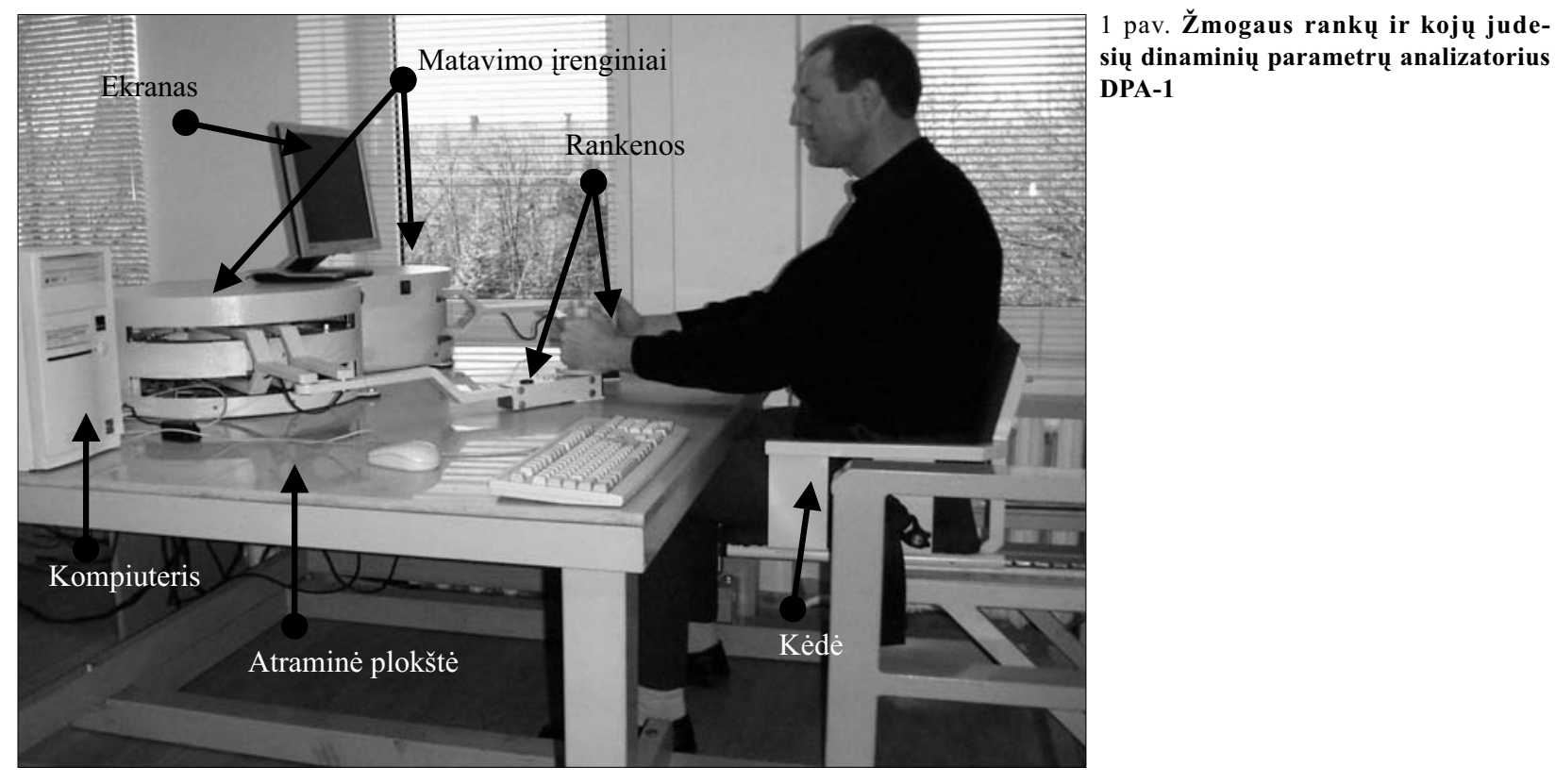

ir kinematiniai rodikliai: greitis, jèga, judesio trajektorija laiko atžvilgiu.

Reakcijos laiko ir judesio greičio rodiklių testavimo eiga buvo ši:

1. „Reakcijos“ užduotis - kaip galima greičiau sureaguoti $\mathfrak{i}$ ekrane atsirandantị taikinị (žalia apskritimą) ir pajudinti prietaiso rankeną. $\mathrm{Pa}-$ aiškinus užduoti, buvo leidžiama atlikti tris bandymus, kurių rezultatai nebuvo fiksuojami. 15 kartų iš eilès atliekama užduotis viena, paskui 15 kartų kita ranka. Tarp bandymų buvo 7-10 sekundžiu pertraukèlè. Tyrimo metu registruojamas dešinès (D-RT) ir kairès (K-RT) rankos reakcijos laikas (ms) bei maksimalusis dešinès (D-RT- $\mathrm{V}_{\max }$ ) ir kairès rankos (K-RT$\left.\mathrm{V}_{\max }\right)$ judesio greitis $(\mathrm{cm} / \mathrm{s})$.

2. Po 5 minučių tiriamasis atliko antrą užduoti „greitumo“. Jos tikslas: pasirodžius ekrane taikiniui, kaip galima greičiau atlikti judesi taikinio link. Po trijų bandymų, kurių rezultatai nebuvo fiksuojami, 15 kartų iš eilès atliekama užduotis viena, paskui 15 kartų kita ranka. Tarp bandymu buvo 7-10 sekundžių pertraukèlè. Tyrimo metu registruotas maksimalusis dešinès $\left(D-V_{\max }\right)$ ir kairès $\left(\mathrm{K}-\mathrm{V}_{\max }\right)$ rankos judesio greitis.

3. Po 5 minučių tiriamasis atliko trečią užduoti „,tikslumo“. Tiriamasis kaip galima greičiau turèjo sureaguoti $\mathfrak{i}$ ekrane pasirodantị taikini ir stumti prietaiso rankeną taip, kad simbolio skritulys ekrane kuo greičiau tikslia trajektorija pasiektų taikinio skrituli ir sustotų jame. Judesio pabaigos momentas buvo fiksuojamas tik tuomet, kai rankenos simbolio centras sustodavo taikinio skritulyje per nustatytą laiką
(100 ms). Paaiškinus užduotị, buvo atliekami trys bandymai, kurių rezultatai nebuvo fiksuojami. Tada 15 kartų iš eilès atliekama užduotis viena, paskui 15 kartų kita ranka. Tarp bandymų buvo 7-10 sekundžių pertraukèlè. Tyrimo metu buvo fiksuojami šie rodikliai: dešinès (D-RTJT) ir kaires (K-RTJT) rankos reakcijos laikas $(\mathrm{ms})$, dešinès $\left(\mathrm{D}-\mathrm{V}_{\max }-\mathrm{JT}\right)$ ir kairès $(\mathrm{K}$ $\mathrm{V}_{\max }-\mathrm{JT}$ ) rankos maksimalusis judesio greitis $(\mathrm{cm} / \mathrm{s})$.

Matematinès statistikos metodai. Apskaičiuotos tiriamų rodiklių aritmetinio vidurkio reikšmès $(\overline{\mathrm{x}})$, vidutinis kvadratinis nuokrypis $(\sigma)$, paklaida $(\mathrm{S} \overline{\mathrm{x}})$, variacijos koeficientas $\left(\mathrm{V}_{\mathrm{A} \%}\right)$, nustatytas rezultatų skirtumo patikimumo lygmuo pagal Stjudento nepriklausomų imčių $t$ kriterijų, atliekant užduotis dešine ir kaire ranka, bei skirtingų imčių rezultatų reikšmingumas.

\section{REZULTATAI}

Dešinès ir kairès rankos reakcijos laiko ir judesio greičio skirtumas. Tyrimo metu nustatytas „reakcijos“ užduoties (atliekant judesius dešine $(265,4 \pm 3,7 \mathrm{~ms})$ ir kaire $(275,2 \pm 5,0 \mathrm{~ms})$ ranka) ir „tikslumo“ užduoties (atliekant judesius dešine $(271,7 \pm 4,5 \mathrm{~ms})$ ir kaire $(278,8 \pm 4,6 \mathrm{~ms})$ ranka) reakcijos laikas (2 pav.). Tyrimo rezultatai parode, kad reikšmingo skirtumo tarp reakcijos laiko rodikliu atliekant judesius skirtingomis rankomis bei atliekant „reakcijos“ (D-RT ir KRT) ir ,tikslumo“ (D-RTJT ir K-RTJT) užduotis nepastebèta $(\mathrm{p}>0,05)$. Taip pat nenustatyta, kad skirtųsi nevienodo sudètingumo užduočiu 
2 pav. Vaikinų kariūnų reakcijos laiko (ms) vidurkiai atliekant „reakcijos“ ir „tikslumo“ užduotis
Pastaba. D-RT ir K-RT - dešimé atliekant „reakcijos“ užduotí; D-RTJT ir K-RTJT — dešinès ir kairès ranku reakcijos trukmè atliekant „tikslumo" užduotị.

1 lentelè. Tiriamųjų reakcijos laikas (ms) atliekant ivairaus sudėtingumo mès nès ir kairès ranku reakcijos trukužduotis ir skirtumo patikimumo reikš-

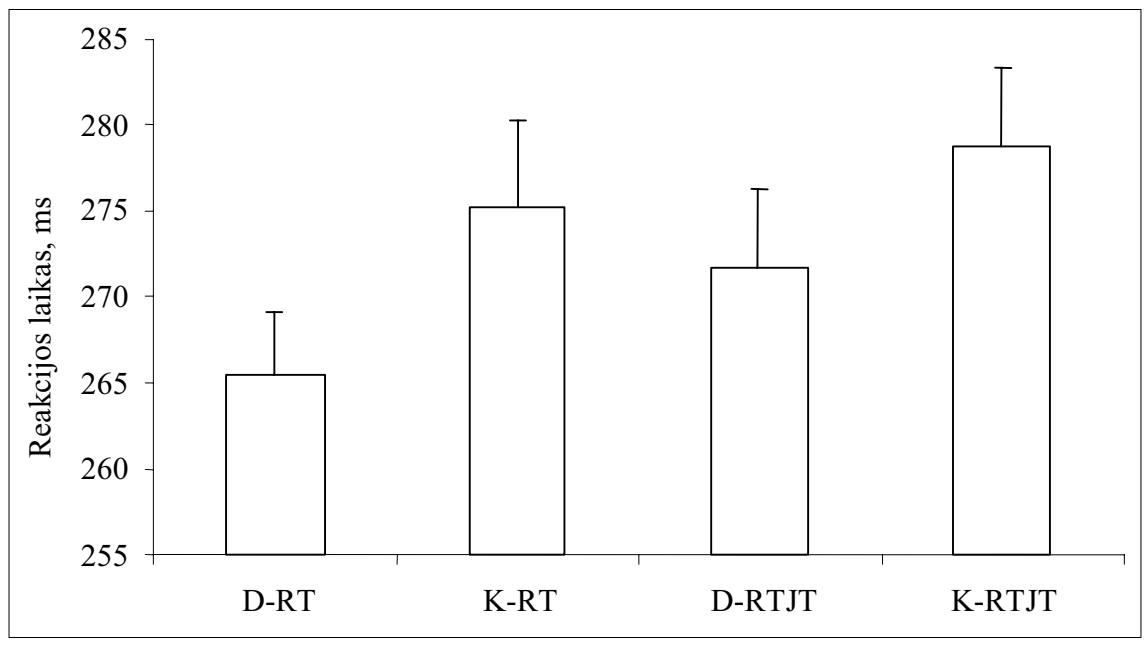

\begin{tabular}{|l|c|c|c|c|}
\hline \multirow{2}{*}{ Užduotis } & \multicolumn{4}{|c|}{ Statistiniai rodikliai } \\
\cline { 2 - 5 } & $\overline{\mathrm{x}}$ & $\sigma$ & $\mathrm{S} \overline{\mathrm{x}}$ & $\mathrm{V}_{\mathrm{A} \%}$ \\
\hline
\end{tabular}

\begin{tabular}{|l|l|l|l|l|}
\hline „Reakcijos“ \\
\hline D-RT & 265,4 & 26,5 & 3,7 & 10,0 \\
\hline K-RT & 275,2 & 35,4 & 5,0 & 12,9 \\
\hline „Tikslumo“ & & & \\
\hline D-RTJT & 271,7 & 32,0 & 4,5 & 11,8 \\
\hline K-RTJT & 278,8 & 32,3 & 4,6 & 11,6 \\
\hline
\end{tabular}

Pastaba: D-RT ir K-RT - dešinès ir kairès ranku reakcijos trukmé atliekant „reakcijos" užduotí; D-RTJT ir K-RTJT — dešinès ir kairès rankų reakcijos trukmė atliekant ,tikslumo" užduotį atitinkamai.

\begin{tabular}{|l|c|c|c|c|}
\hline Stjudento $\boldsymbol{t}$ kriterijaus reikšmės \\
\hline D-RT / K-RT & $-1,567$ & $>0,05$ & & \\
\hline D-RTJT / K-RTJT & $-1,098$ & $>0,05$ & & \\
\hline D-RT / D-RTJT & $-1,073$ & $>0,05$ & & \\
\hline K-RT / K-RTJT & $-0,528$ & $>0,05$ & & \\
\hline
\end{tabular}

reakcijos laikas atliekant judesi ta pačia ranka ( $p>0,05)$ (1 lent.).

Reikšmingo judesių greičio rodiklių skirtumo atliekant tas pačias užduotis dešine ir kaire ranka nebuvo pastebèta $(p>0,05)$, išskyrus „tikslumo“ užduoti - tiriamieji judesi greičiau atliko kaire ranka $(\mathrm{t}=2,224 ; \mathrm{p}<0,001)$ (2 lent.). Tos pačios rankos judesio greičio rodikliai skyrèsi priklausomai nuo užduoties sudètingumo (2 lent.). Nustatyta, kad didžiausios judesio greičio reikšmès buvo pastebimos tiriamiesiems atliekant „greitumo“ užduotị (D- $\mathrm{V}_{\max }-239,6 \pm 4,2$ ir $\mathrm{K}$ $\mathrm{V}_{\max } 237,5 \pm 6,2 \mathrm{~cm} / \mathrm{s}$ ), mažiausios — ,reakcijos“ užduoti (D- $\mathrm{V}_{\max }-\mathrm{RT} 74,3 \pm 4,0$ ir $\mathrm{K}-\mathrm{V}_{\max }-\mathrm{RT}$ 71,4 $\pm 4,7 \mathrm{~cm} / \mathrm{s}$ ) (3 pav.). „Greitumo“ užduoties greičio rodikliai buvo statistiškai reikšmingai didesni nei ,reakcijos“ $(\mathrm{t}=28,558$ ir $\mathrm{t}=21,347$; $\mathrm{p}<0,001)$ ir ,tikslumo“ $(\mathrm{t}=12,208$ ir $\mathrm{t}=13,613$; $\mathrm{p}<0,001)$ užduočių (2 lent.).

Reakcijos laiko ir judesių greičio rodiklių sklaidos analizè. Norèdami įvertinti tiriamų rodiklių rezultatų sklaida, apskaičiavome skirtingų užduočių variacijos koeficientus. Šie koeficientai leidžia palyginti skirtingų reikšmių sklaidą. Sporto praktikoje dažniausiai požymių variantų sklaida yra laikoma maža, jeigu variacijos koeficientas siekia nuo 0 iki $10 \%$, vidutine - nuo 10 iki $20 \%$, ir didelè - daugiau kaip 20\% (Gonestas, Strielčiūnas, 2003).

Analizuojant reakcijos laiko variacijos koeficientus pastebėta, kad skirtingų užduočiu rodikliai atliekant judesius dešine ir kaire ranka varijuoja nuo 10,0 iki $12,9 \%$. Taigi šio rodiklio variantų sklaida yra nedidelè. Testo sudètingumas variacijos koeficientui iš esmès neturèjo ittakos.

Didesni rezultatu variacijos koeficientai pastebimi analizuojant judesiu greičio rezultatus. „Reakcijos" užduoties variacijos koeficiento rodikliai svyruoja nuo 38,1 iki 46,6\%, ,greitumo“ - 12,3-18,5\% ir "tikslumo“ - 18,6$21,4 \%$. Nors jie yra mažesni, rodo vidutinę ir didelę judesiu greičio rodiklių sklaidą. Tai leidžia manyti, kad tiriamieji, atlikdami skirtingas užduotis, renkasi individualia judesio strategiją. 


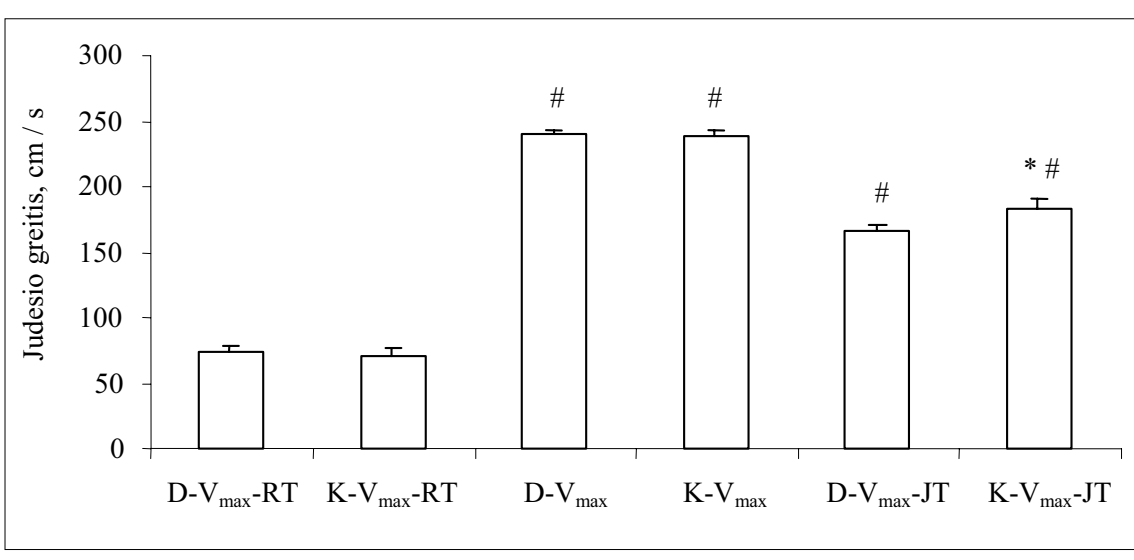

3 pav. Vaikinų kariūnų judesių greičio (cm / s) vidurkiai atliekant ,reakcijos“, "greitumo“ ir "tikslumo“ užduotis

Pastaba. D- $\mathrm{V}_{\max }-\mathrm{RT}$ ir $\mathrm{K}-\mathrm{V}_{\max }-\mathrm{RT}-\mathrm{de}-$ šinès ir kairès rankų maksimalieji judesio greičiai atliekant ,,reakcijos“ užduoti; D$\mathrm{V}_{\max }$ ir $\mathrm{K}-\mathrm{V}_{\max }$ - dešinès ir kairès ranku maksimalieji judesio greičiai atliekant ,greitumo“ užduoti; D- $\mathrm{V}_{\max }-\mathrm{JT}$ ir $\mathrm{K}-\mathrm{V}_{\max }$ JT — dešinès ir kairès rankų maksimalieji judesio greičiai atliekant „tikslumo“ užduoti. * - p $<0,05$, lyginant dešinès ir kairès rankos rezultatus; \#- $\mathrm{p}<0,001$, lyginant skirtingų užduočių tos pačios rankos rezultatus.

\begin{tabular}{|c|c|c|c|c|}
\hline \multirow{2}{*}{ Užduotis } & \multicolumn{4}{|c|}{ Statistiniai rodikliai } \\
\cline { 2 - 5 } & $\overline{\mathrm{x}}$ & $\sigma$ & $\mathrm{S} \overline{\mathrm{x}}$ & $\mathrm{V}_{\mathrm{A} \%}$ \\
\hline
\end{tabular}

2 lentelè. Tiriamųju judesių greitis $(\mathrm{cm} / \mathrm{s})$ atliekant skirtingas užduotis ir skirtumo patikimumo reikšmès

\begin{tabular}{|c|c|c|c|c|}
\hline \multicolumn{5}{|c|}{ „Reakcijos“ } \\
\hline $\mathrm{D}-\mathrm{V}_{\max }-\mathrm{RT}$ & 74,3 & 28,3 & 4,0 & 38,1 \\
\hline $\mathrm{K}-\mathrm{V}_{\max }-\mathrm{RT}$ & 71,4 & 33,2 & 4,7 & 46,6 \\
\hline \multicolumn{5}{|l|}{ „Greitumo“ } \\
\hline $\mathrm{D}-\mathrm{V}_{\max }$ & 239,6 & 29,6 & 4,2 & 12,3 \\
\hline $\mathrm{K}-\mathrm{V}_{\max }$ & 237,5 & 43,9 & 6,2 & 18,5 \\
\hline \multicolumn{5}{|l|}{ „Tikslumo“ } \\
\hline $\mathrm{D}-\mathrm{V}_{\max }-\mathrm{JT}$ & 165,9 & 30,8 & 4,4 & 18,6 \\
\hline $\mathrm{K}-\mathrm{V}_{\max }-\mathrm{JT}$ & 183,9 & 48,1 & 6,8 & 21,4 \\
\hline
\end{tabular}

Stjudento $t$ kriterijaus reikšmès

\begin{tabular}{|l|c|c|l|l|}
\hline $\mathrm{D}-\mathrm{V}_{\max }-\mathrm{RT} / \mathrm{K}-\mathrm{V}_{\max }-\mathrm{RT}$ & 0,467 & $>0,05$ & & \\
\hline $\mathrm{D}-\mathrm{V}_{\max } / \mathrm{K}-\mathrm{V}_{\max }$ & 0,284 & $>0,05$ & & \\
\hline $\mathrm{D}-\mathrm{V}_{\max }-\mathrm{JT} / \mathrm{K}-\mathrm{V}_{\max } \mathrm{JT}$ & $-2,224$ & $<0,05$ & & \\
\hline $\mathrm{D}-\mathrm{V}_{\max }-\mathrm{RT} / \mathrm{D}-\mathrm{V}_{\max }$ & $-28,588$ & $<0,001$ & & \\
\hline $\mathrm{D}-\mathrm{V}_{\max }-\mathrm{RT} / \mathrm{D}-\mathrm{V}_{\max }-\mathrm{JT}$ & $-15,506$ & $<0,001$ & & \\
\hline $\mathrm{D}-\mathrm{V}_{\max } / \mathrm{D}-\mathrm{V}_{\max }-\mathrm{JT}$ & 12,208 & $<0,001$ & & \\
\hline $\mathrm{K}-\mathrm{V}_{\max }-\mathrm{RT} / \mathrm{K}-\mathrm{V}_{\max }$ & $-21,347$ & $<0,001$ & & \\
\hline $\mathrm{K}-\mathrm{V}_{\max }-\mathrm{RT} / \mathrm{K}-\mathrm{V}_{\max }-\mathrm{JT}$ & $-13,612$ & $<0,001$ & & \\
\hline $\mathrm{K}-\mathrm{V}_{\max } / \mathrm{K}-\mathrm{V}_{\max }-\mathrm{JT}$ & 5,825 & $<0,001$ & & \\
\hline
\end{tabular}

Pastaba. D-Vmax-RT ir K-Vmax-RT dešinès ir kairès rankų maksimalieji judesio greičiai atliekant „,reakcijos“ užduotį; D-Vmax ir K-Vmax — dešinès ir kairès rankų maksimalieji judesio greičiai atliekant ,greitumo“ užduoti; D-Vmax-JT ir K-Vmax-JT - dešinès ir kairès rankų maksimalieji judesio greičiai atliekant „tikslumo“ užduoti.

\section{REZULTATŲ APTARIMAS}

Tyrimo metu buvo nustatyta, kad atliekant užduotis skirtingomis rankomis reakcijos laiko rodikliai reikšmingai nesiskiria. Mūsų žiniomis, tai sutampa su kitų autorių tyrimo duomenimis (YinChen Shen, Franz, 2005), kurie nerodo esminio skirtumo tarp reakcijos laiko atliekant judesi dešine ir kaire ranka. Kitų autoriu pateikiami reakcijos laiko rodikliai atliekant judesius dominuojančia ir nedominuojančia ranka skiriasi (Бердичевская, 1999; Brouwer et al., 2001).

İomu pastebèti, kad užduoties sudètingumas reakcijos laiko reikšmių mūsų tyrimo metu nepaveikè. Gana keista, kad atliekant „tikslumo“ testa, kuriuo buvo modeliuota „dviguba“ užduotis, reakcijos laikas nesulètėjo. Tai iš esmès prieštarauja
Hiko dèsniui, pagal kurį reakcijos laikas yra tiesiog proporcingas užduoties sudètingumui (Jensen, 1998; Gignac, Vernon, 2004), t. y. kuo daugiau informacijos perduodama stimulu, tuo ilgesnis yra reakcijos laikas (Schmidt, Lee, 1999). Manome, kad gautus tyrimo duomenis galima paaiškinti šitaip: atlikdami „tikslumo“ užduoti, tiriamieji turejjo sureaguoti i netikètą, bet jau pažistama, t. y. anksčiau sutiktą stimula, ir tai jiems leido pakankamai greitai orientuotis bei priimti reikiamą sprendima, nors užduotis ir buvo sunkesnè. Taigi galime daryti prielaidą, kad iprastos užduoties atlikimo sąlygos (iš anksto žinomas dirgiklis) ir prieš tai daug kartų pakartotas judesys galejjo prislopinti užduoties sudetingumo laipsni, todèl trečios užduoties reakcijos laiko rodikliai reikšmingai nesiskyrè nuo pirmos $(\mathrm{p}>0,05)$. 
Analizuojant „reakcijos“ ir „greitumo“ užduočių judesių greiti, statistiškai reikšmingo skirtumo tarp dešinès ir kairès rankos rodikliu nenustatyta $(p>0,05)$, tačiau reikšmingas $(p<0,05)$ kairès ir dešinès rankos rezultatų skirtumas buvo pastebètas tiriamiesiems atliekant sudètingesnę „tikslumo“ užduoti, kurios metu jie turejjo kaip galima greičiau pradèti ir atlikti judesi bei tiksliai pataikyti i nustatytą taikinị. Panašius dinaminiu ir kinematinių rodiklių dešinès ir kairès rankos asimetrijos skirtumus priklausomai nuo motorinès užduoties sudetingumo nurodo ir kiti mokslininkai (Brouwer, et al., 2001; Lewis et al., 2002). Yra nustatyta (Schmidt, Lee, 1999), kad gana sunku suderinti judesiu greitumą ir tiksluma, nes greičiau atliekant judesi sumažėja jo trukmé, kartu ir koregavimo galimybès. Tai, kad judesiu greičio rodikliai priklauso nuo užduoties sudètingumo, rodo ir mūsų atlikto tyrimo rezultatai - greitą ir tikslų judesi tiriamieji abiem rankom atliko lečciau nei paprasta greita judesi.

Tyrimo metu buvo pastebètas analizuojamu rodiklių sklaidos skirtumas. Reakcijos laiko rodiklių variacijos koeficientai buvo mažesni (svyruoja nuo 4,0 iki 12,8\%) nei judesiu greičio rodiklių (svyruoja nuo 12,3 iki 46,6\%). Taigi užduoties sudetingumas labiau paveikè judesiu greičio nei reakcijos laiko rezultatu sklaidą. Gauti rezultatai leidžia manyti, kad: 1) reakcijos laikas yra stabiliau valdomas rodiklis; 2) tiriamieji, norèdami kuo tiksliau atlikti skirtingo sudètingumo testus, renkasi skirtinga judesio greičio atlikimo strategija; 3) tiriamiesiems davus vieną užduoti „tik greitai sureaguoti“" neakcentuojant tolimesnio judesio atlikimo greičio $-\mathrm{V}_{\max }$ nebuvo valdomas rodiklis, todèl jo sklaida pastebimai didesnè.

Baigiant aptarti rezultatus, reiketų išanalizuoti ir tyrimo trūkumus:

1. Nepakankamai dèmesio skyrème tiriamujų dominuojančiai ir nedominuojančiai rankai nustatyti.

2. Taikinys, i kuri turejo sureaguoti tiriamieji, atlikdami visas tris užduotis, buvo taip sumodeliuotas, kad visada atsirasdavo toje pačioje vietoje, o tai galëjo sumažinti netikètumo efektą reaguojant.

3. Atliekamo judesio pasimokymas galëjo susilpninti užduoties sudètinguma.

Manome, kad šie aspektai paveike gautus tyrimo rezultatus ir ị tai reikètu atsižvelgti atliekant tolimesnius tyrimus.

\section{IŠVADOS}

1. Reakcijos laiko rodikliai atliekant judesius dešine ar kaire ranka nesiskiria, taip pat šio rodiklio nepaveikè ir užduoties sudètingumas.

2. Judesių greičio rodikliai priklauso nuo užduoties sudètingumo: greitą ir tikslų judesi tiriamieji atliko lèčiau nei paprastą greita. Testo, kuri atliekant reikejjo tik greitai reaguoti i pasirodžiusį taikini, judesių greičio reikšmès buvo mažiausios.

3. Reakcijos laiko rodikliu sklaida (variacijos koeficientas) yra mažesnè (svyruoja nuo 4,0 iki $12,8 \%$ ) nei judesių greičio rodiklių (svyruoja nuo 12,3 iki 46,6\%). Užduoties sudètingumas labiau paveikè judesių greičio nei reakcijos laiko rezultatų sklaidą.

\section{LITERATŪRA}

Brouwer, B., Sale, M. V., Nordstrom, M. A. (2001). Asymmetry of motor cortex excitability during a simple motor task: Relationships with handedness and manual performance. Experimental Brain Research, 138 (4), 467-476.

Enoka, R. (2002). Neuromechanics of Human Movement. Champaign, Illinois: Human Kinetics.

Georgopoulos, A. P., Taira, M., Lukashin, A. (1993). Cognitive neurophysiology of motor cortex. Science, 260, 47-52.

Gignac, G. E., Vernon, P. A. (2004). Reaction time and the dominant and non-dominant hands: An extension of Hick's Law. Personality and Individual Differences, 36, 733-739.

Gonestas, E., Strielčiūnas, R. (2003). Taikomoji statistika. Vadovèlis kūno kultūros ir sporto specialybių studentams (bakalaurams, magistrantams) bei doktorantams. Kaunas: LKKA.
Hodges, N. J., Franks, I. M. (2002). Modeling coaching practice: The role of instruction and demonstration. Journal of Sport Sciences, 20, 793-811.

Jensen, A. (1998). The G Factor: The Science of Mental Ability. Westport: Praeger.

Kelso, J. A. S. (1999). Dynamic Patterns: The SelfOrganization of Brain and Behavior. Cambridge: MIT Press.

Latash, M. L. (1998). Neurophysiological Basis of Movement. Champaign, Illinois: Human Kinetics.

Lewis, S. R., Duff, S. V., Gordon, A. M. (2002). Manual asymmetry during object release under varying task constraints. The American Journal of Occupational Therapy, 56 (4), 391—401.

Muckus, K., Daniševičius, J., Kriščiukaitis, A. (1999). Kompiuterizuota dinamografinè sistema sudetingajai psichomotorinei reakcijai tirti. Ugdymas. Kūno kultūra. Sportas, 1 (30), 51-56. 
Muckus, K. (2003). Psichomotorinès reakcijos ir jos komponentu priklausomybè nuo judèjimo užduoties sunkumo. Ugdymas. Kūno kultūra. Sportas, 4 (49), 3540.

Muckus, K., Zdanavčienè. S., Čižauskas, A. (2000). Krepšininku psichomotorinès reakcijos kaip testo kokybès ivertinimas. Ugdymas. Küno kultūra. Sportas, 3 (36), $24-32$.

Rose, D. J. (1996). A Multilevel Approach to the Study of Motor Control and Learning. Boston: Benjamin / Cummings.

Schmidt, R. A., Lee, T. D. (1999). Motor Control and Learning: A Behavioral Emphasis. Champaign, Illinois: Human Kinetics.

Shen Yin-Chen, Franz, E. A. (2005). Hemispheric competition in left-handers on bimanual reaction time tasks. Journal of Motor Behavior, Vol. 37, 1, 3-9.
Skernevičius, J., Raslanas, A., Dadelienè, R. (2004). Sporto mokslo tyrimu metodologija. Vilnius: Sporto informacijos centras.

Skurvydas, A. (1998). Judesiu valdymo ir sporto fiziologijos konspektai. Mokomasis leidinys. Kaunas: LKKI. P. 136.

Skurvydas. A., Stanislovaitis, A., Mačiukas A. (1996). Greitumo lavinimo pagrindai. Treneris, 2, 15-22.

Stergiou, N. (2004). Innovative Analyses of Human Movement. Champaign, Illinois: Human Kinetics.

Wolpert, D. M., Doya, K., Kawato, M. (2003). A unifying computational framework for motor control and social interaction. Philosophical Transactions. Biological Sciences, 358, 593-602.

Бердичевская, Е. М. (1999). Профиль межполушарной ассиметрии и двигательные качества. Теория $u$ практика физической культуры, 9, 38-42.

\title{
THE ANALYSIS OF THE MILITARY'S ARM PSYCHOMOTOR PROPERTIES USING THE ANALYSER DPA-1
}

\author{
Ilona Judita Zuozienė ${ }^{1}$, Albertas Skurvydas ${ }^{1}$, Dalia Mickevičienė ${ }^{1}$, Rytis Vasiliauskas ${ }^{2}$, Arūnas \\ Krasauskas ${ }^{2}$, Jūratè Kudirkaité ${ }^{1}$ \\ Lithuanian Academy of Physical Education ${ }^{l}$, Kaunas, The General Jonas Žemaitis Military Academy of \\ Lithuania', Vilnius, Lithuania
}

\begin{abstract}
The aim of the research - to identify the peculiarities of reaction time and movement speed performing moves by the right and left arms subject to the level of movement complexity. The following questions were aimed to be discussed in the study: 1) is there any difference between reaction time and movement speed performing a movement by the right and left arms?; 2) do reaction time and movement speed depend on the level of movement complexity?; 3) what variation indices of the studied parameters performing moves by the right and left arms exist?; 4) does the complexity of a task impact the result variability of the studied parameters? The studies were executed in the Laboratory of Human Motorics at the Lithuanian Academy of Physical Education (LAPE) using the new original analyser DPA-1 for the analysis of dynamic parameters of human leg and arm movement. The scientists at the LAPE and the specialists of the joint-stock company "Katra" created this device. 50 healthy first-year students of the Lithuanian Military Academy participated in the research. Their age was $19.1 \pm 0.11$ years, height $-182.3 \pm 1.06 \mathrm{~cm}$, body mass $-76.9 \pm 1.13 \mathrm{~kg}$. The results of the research showed that performing moves by the right and left arms reaction time indices did not differ $(p<0.05)$; the complexity of a task did not influence this index as well. While analysing the dependence of movement speed indices on the complexity of a task it was found out that a quick and accurate movement was performed slower than a simple quick movement. The dispersion of reaction time indices was smaller than that of movement speed indices. The complexity of a task impacted the variability of movement speed results more than the variability of reaction time results.
\end{abstract}

Keywords: reaction time, movement speed, the complexity of a task.

Gauta 2005 m. rugpjūčio 22 d.

Received on August 22, 2005

Priimta $2005 \mathrm{~m}$. lapkričio $16 \mathrm{~d}$. Accepted on November 16, 2005
Ilona Judita Zuozienè

Lietuvos kūno kultūros akademija

(Lithuanian Academy of Physical Education)

Sporto g. 6, Kaunas LT-44221

Lietuva (Lithuania)

Tel+370 37302666

E-maili.zuoziene@1kka.1t 